International Journal of Social Science and Economic Research

ISSN: 2455-8834

Volume:06, Issue:02 "February 2021"

\title{
ROAD TRANSPORT IN INDIA -AN OVERVIEW
}

\author{
Sunil Kumar $\mathrm{P}^{1}$ and B. Jayarama Bhat ${ }^{2}$ \\ 1Research Scholar, Department of PG Studies and Research in Economics, Kuvempu University, Jnana \\ Sahyadri, Shankaraghatta, Shivamogga \\ 2Professor of Economics, Department of PG Studies and Research in Economics Kuvempu University, \\ Jnana Sahyadri, Shankaraghatta, Shivamogga
}

DOI: 10.46609/IJSSER.2021.v06i02.016 URL: https://doi.org/10.46609/IJSSER.2021.v06i02.016

\begin{abstract}
Road connectivity is a vital for the sustained and inclusive growth of the country. It facilitates the movement of passengers and freight across the country. India's transportation sector has a share of 4.8 per cent in the Gross Domestic Product (GDP) in 2011-12. Although National Highways constituted about 1.80 per cent of the total network as on March 2016, they carried 40 per cent of the total road tariff. The total road length of the country increased significantly from 3.99 lakh $\mathrm{kms}$ in 1951 to 56.03 lakh $\mathrm{kms}$ in 2016. During the years 1951-2016 growth of Compound Annual Growth Rate (CAGR) was 4.1 per cent. During the same period surfaced road treatment increased from 39.26 per cent to 62.5 per cent. India's road density of $170 \mathrm{~km}$ was higher than that of Japan $(0.91 \mathrm{~km})$, the USA $(0.68 \mathrm{~km})$, China $(0.47 \mathrm{~km})$ and Brazil $(0.18$ $\mathrm{km})$. Further, the researchers in this paper examined the history of development of road transport India and analyzed Five Year Plans and brief overview of road network 1951 to 2016. Furthermore, researchers find out the growth of road transport between the periods of preliberalization and post-liberalization. And analyses CAGR of Road Network. The present study has been conducted based on the secondary data.
\end{abstract}

Key Words: Road Transport, Five Year Plans, Road Network, Road Density, International Comparison, CAGR.

\subsection{Introduction}

Road network is a vital for the sustained and inclusive growth of the country. It facilitates the movement of passengers and freight across the country. It promotes efficiency in the economy by minimizing total transportation cost in terms of economies of production, distribution and consumption. The role of road transport among the different modes of transport is dominant 
International Journal of Social Science and Economic Research

ISSN: 2455-8834

Volume:06, Issue:02 "February 2021"

because of its last mile connectivity or feeder service. India is basically a country of villages which has more than 6.41 villages and 83 crore of the people lives in villages. The geographical environment, area and climate conditions favour the road transport. Road transport also acts as feeder service to railway, shipping and air traffic. It has emerged as the dominant segment in India's transportation sector with a share of 4.8 per cent in India's Gross Domestic Product (GDP) in 2011-12. Although National Highways constituted 1.80 per cent of the total network as on March 2016, they carried 40 per cent of the total road traffic1.

The total road length of the country increased significantly from 3.99 lakh kms in 1951 to 56.03 lakh kms in 2016 with the CAGR of 84.1 per cent during the years 1951-2016 and also surfaced road formed increased from39.26 per cent increased 62.5 per cent during the period between 1951 and 2016. India's road density at $170 \mathrm{~km}$ was higher than that of Japan $(0.91 \mathrm{~km})$, the USA $(0.68 \mathrm{~km})$, China $(0.47 \mathrm{~km})$ and Brazil $(0.18 \mathrm{~km}) 2$.The state-wise shows that the Maharashtra $(613418 \mathrm{kms})$ accounted for the largest share of 13.04 per cent in total network of roads for the year up to the period March 2016 followed by Uttar Pradesh share of 8.98 per cent, Karnataka share of 7.35 per cent, Assam share of 7.01 per cent and West Bengal share of 6.73 per cent and combined these states accounted for about a share of 43.11 per cent of total road length of the country3.

Myrdal's theory of Backwash and spread effects quoted that the stronger spread effects will attain a higher level of economic development because the development is accompanied by improved transportation and communication, higher levels of education and a more dynamic communion of ideas and value of all of which tend to strengthen the forces for the centrifugal spread of economic expansion.

\subsubsection{Road Connectivity in India.}

Table 01 gives data on Catogory of Road Connectivity in India, as on March 2017.

Table-01

Road Connectivity in India

\begin{tabular}{|c|c|c|}
\hline Category of Roads & Road Length $($ Kms) & Percentage Road \\
\hline $\mathbf{( 0 1 )}$ & $\mathbf{( 0 2 )}$ & $\mathbf{( 0 3 )}$ \\
\hline 1. National Highways & $1,14,158$ & 1.94 \\
\hline 2.State Hihgwats & $1,75,036$ & 2.97 \\
\hline 3. Other PWD Roads & $5,86,181$ & 9.93 \\
\hline
\end{tabular}


International Journal of Social Science and Economic Research

ISSN: 2455-8834

Volume:06, Issue:02 "February 2021"

\begin{tabular}{|c|c|c|}
\hline 4.Rural Roads & $41,66,916$ & 70.65 \\
\hline 5.Urban Roads & $5,26,483$ & 8.93 \\
\hline 6.Projects Roads & $3,28,897$ & 5.58 \\
\hline Total & $58,97,671$ & 100.00 \\
\hline
\end{tabular}

Source: Basic Road Statistics of India, 2016-17 Government of India, Ministry of Transport and Highways, IDA Building, Jammanagar House, Shahjahan Road, New Delhi, pp.2-7. (http://www.basicroadstatisticsofindia.com Retrieved on 20-02-2020, 11.00 Am.)

\subsection{Objectives of the Study}

It is attempted in this paper.

1.To analyse the history of development of road transport in India and the road transport under the Five-Year Plans.

2. To overview the India's total road network (1951 to 2016).

3. To find out the growth of road transport between the of pre-liberalization and postliberalization.

\subsection{Paper Scheme}

As the study concentrates nearly on road transport in India the secondary data is collected to examine the growth of overall changes in the road network from 1951 to 2016. Census reports, journals, articles, books, periodicals and other reports published by government are referred to collect the secondary data (Population figures the data is collected from 1951 to 2011 census reports).

\subsection{Review of Literature}

A review of past research helps in identifying the conceptual and methodological issues relevant to the study. Many studies have already been published on the broad topics of transport and rural development in general. The review is restricted keeping the size of the paper in view.

William L. Garison (1960), in a study entitled Connectivity of the Interstate Highway System, discussed some of the characteristics of the inter-state highway system and relevance of the research problem in USA.

Vijayaraghavan (1995) in his study on Strategic Options for State Road Transport Undertakings in India, attempted to assess the present strategic position of State Road 
Transport Undertakings (SRTUs) through an elaborate SWOT analysis and chalk-out strategic options for them in the present emerging environment of changing needs and attitudes.

A Report of Food and Agriculture Organization (1996) stated that adequate road network, electricity and telecommunication provisions are very important for stimulating agricultural investment and growth.

Mazharul (1998), in his article on The Accident Problem on Rural Highways, talked about the key aspects of rural road accidents in general and Dhaka - a rich highway of Bangladesh in particular. This study found that accidents in rural areas were more severe than in urban and semi-urban areas.

A. Talvitie (2000), in his study on Evaluation of Road Projects and Programmes in Developing Countries, made economic evaluation of World Bank support to road projects in developing countries using Cost-Benefit Analysis.

In his book entitled Geography of Transport Development in India by B.C. Vaidya (2003), consist of 29 chapter and explained transport development mainly under three sections.1. Indian transport systems 2. Metropolitan transportation, and 3. Regional Transport System. Further, the study dealt with the varied factors of rail and road transport in India by giving geographical significance to the region.

In an Article on Road Safety Improvement: A Challenging Issue on Indian Roads, Sing A.P. et al. (2009), argued that the number of people is losing their lives in road accidents. Further discussed road accidents and their adverse effects, prevention and control and some recent approaches to improve the supply on roads.

Tarique (2009) in his Paper on Rural Infrastructure and Economic Development, described that the transportation, energy, telecommunication and related infrastructure transforms into poorly functioning domestic markets with little spatial and temporal integration, low price transmission and weak international competitiveness and failure to accelerate investments in rural infrastructure will make a mockery of efforts to achieve the Minimum Development Goods in poor developing countries.

In his study on Transport Infrastructure in India: Developments, Challenges and Lessons from Japan, by Pravakon Sahoo (2011), explained that the Current Status and Issues to India's transport infrastructure, mainly roads, railways, airports and ports. Further, study looks at development of transport infrastructure in Japan which had drawn useful policy lessons for India. 
International Journal of Social Science and Economic Research

ISSN: 2455-8834

Volume:06, Issue:02 "February 2021"

A Paper entitled Union Budget 2017-18: A Take-off for Infrastructure Sector carried out by Krishna Dev (2017) argued that increased required in provision of services, roads, along with high capacity corridors to cater to the needs of local motorised and non-motorised traffic and social requirements of pedestrian/cattle under passes. Further, pointed out the road sector budget allocation increased to ₹ 64,900 crore in $2017-18$ which was 27 per cent of total allocation or transport sector.

\subsection{Development of Road Transport}

The history of development of road transport in India started from 1929 with the constitution of Jayakar Committee by the British government. This committee had realized the important role of the central government in the development of roads. Details of the development plans for roads are as follows:

1.4.1. Road Development Plans; Successive Five-Year Plans aimed at achieving higher road densities and managed to over achieve it. The criteria, targets and achievement for road development plans are presented in Table 2.

Table 2

Basic for Assessment, Assessed Targets and Expected Densities in the Road Development Plans

\begin{tabular}{|c|c|c|c|c|}
\hline $\begin{array}{l}\text { Name of the } \\
\text { Plan }\end{array}$ & Basis of fixation of targets & $\begin{array}{l}\text { Targets } \\
(\mathrm{kms})\end{array}$ & $\begin{array}{l}\text { Achievement } \\
(\mathbf{k m s})\end{array}$ & $\begin{array}{l}\text { Target } \\
\text { Density- All } \\
\text { Roads (km per } \\
\text { sq.km) }\end{array}$ \\
\hline (01) & (02) & (03) & (04) & $(05)$ \\
\hline $\begin{array}{l}\text { 1. Nagpur Plan }{ }^{14} \\
(1943-61)\end{array}$ & $\begin{array}{l}\text { Length of ODRs }+ \text { VRs } \\
\text { assessed on the basis of } \\
\text { number of villages with } \\
\text { population } 500 \text { and less, 501- } \\
1000,1001-2000 \text { and 2001- } \\
5000\end{array}$ & $3,32,335$ & $5,00,802$ & 0.32 \\
\hline $\begin{array}{l}\text { 2. Bombay Plan } \\
(1961-81)\end{array}$ & $\begin{array}{l}\text { Length based on the number of } \\
\text { villages with population less } \\
\text { than 500, 501-1000, 1001- } \\
2000 \text { and } 2000-5000\end{array}$ & $6,51,780$ & $9,12,684$ & 0.46 \\
\hline $\begin{array}{l}\text { 3. Lucknow Plan } \\
\text { (1981-2001) }\end{array}$ & $\begin{array}{l}\text { Length assessed on the basis } \\
\text { of number of villages and } \\
\text { towns }\end{array}$ & $21,89,000$ & $2,994,000$ & 0.82 \\
\hline
\end{tabular}

Source: 1) Rural Roads, Mohapatra and Chandrasekhar, Rural Infrastructure, India 
International Journal of Social Science and Economic Research

ISSN: 2455-8834

Volume:06, Issue:02 "February 2021"

Infrastructure Report 2007, Oxford University Press, New Delhi, p. 111.

2) Rural Road Development Vision, 2025, Government of India (Draft).

\subsection{Road Transport under Five Year Plans;}

The Nagpur Plan has provided the foundation for the development of roads in India and special importance was given to the development of roads under Five Year Plans. This plan aimed at increasing the surfaced road length from 88,000 to $1,23,000 \mathrm{~km}$ and the un-surfaced road from $1,32,000 \mathrm{~km}$ to $2,08,000 \mathrm{kms} 15$. As discussed as under.

$>$ First Five-Year Plan (1951-56); during this period ₹ 147 crore was spent on the development of roads and road transport. During this plan period 2,09,000 kms of surfaced roads were constructed.

$>$ Second Plan (1956-61); during this period ₹ 242 crore was earmarked for the development of roads and road transport. During the same period 2.63 lakh kms of surfaced roads were laid against the target of 2.29 lakh kms.

$>$ Third Plan (1961-66); during this plan period ₹ 467 crore was allocated for the development of roads and road transport. 3.43 lakh kms of surfaced roads were laid against the target of 2.76 lakh kms.

$>$ Fourth Plan (1969-74); a total of ₹ 990 crores was allocated for the development of roads and road transport. 4.99 lakh kms of surfaced roads were laid against the target of 84.50 lakh kms.

$>$ Fifth Plan (1974-79); during this plan period ₹ 2,204 crore was incurred on the development of road transport. About 5.96 lakh kms of surfaced roads were laid.

$>$ Sixth Plan (1980-85); a total of ₹ 5082 crores was earmarked on the development of road transport during this period. 8.33 lakh $\mathrm{kms}$ of surfaced roads were laid during the same period and the total length of roads was 14.91 lakh kms in 1984-85.

$>$ Seventh Plan (1985-90); during this plan period ₹ 8,486 crore was incurred on the development of road transport. About 9.60 lakh kms of surfaced roads were constructed.

$>$ Eighth Plan (1992-97); in this period, it was proposed to spend ₹ 17,060 crore on the development of road transport.

$>$ Ninth Plan (1997-2002); During this plan period ₹ 1,21,324 crore was incurred on the development of total transport sector.

$>$ Tenth Plan (2002-07); The Tenth plan outlay for the central sector roads programme is ₹ 59,480 crore.

$>$ Eleventh Plan (2007-12); For the roads and bridges sector, the Eleventh Plan envisages a total investment of ₹ $3,14,152$ crore. 
International Journal of Social Science and Economic Research

ISSN: 2455-8834

Volume:06, Issue:02 "February 2021"

Twelfth Plan (2012-17); The Twelfth Plan outlay for the central sector roads (including private sector investment) ₹ 4,21,789 crore $^{16}$.

\subsection{India's Total Road Network}

The road network of the country consists of National Highway (SH), Other Public Works Departments (OPWD) Roads, Rural Roads, Urban Roads (UR) and Project Roads (PR). The highlights of the total roads in India from 1951 to 2016 are indicated in Table 3.

Table 3

Total Road Network in India, 1950-51 to 2015-16

(Road Length in kms.)

\begin{tabular}{|l|l|l|l|l|}
\hline Year & $\begin{array}{l}\text { Road Length } \\
(\mathbf{K m s})\end{array}$ & $\begin{array}{l}\text { Decadal Growth of } \\
\text { Road Network }(\%)\end{array}$ & $\begin{array}{l}\text { Length of Road } \\
\text { per } \\
\text { Population* }\end{array}$ & $\begin{array}{l}\text { Pakh } \\
\text { sq.kms. }\end{array}$ \\
\hline $\mathbf{( 0 1 )}$ & $\mathbf{( 0 2 )}$ & $\mathbf{( 0 3 )}$ & $\mathbf{( 0 4 )}$ & $\mathbf{( 0 5 )}$ \\
\hline $1950-51$ & $3,99,942$ & - & 110.76 & 12.16 \\
\hline $1960-61$ & $5,24,478$ & 31.13 & 119.48 & 15.95 \\
\hline $1970-71$ & $9,14,979$ & 74.45 & 161.59 & 27.83 \\
\hline $1980-81$ & $14,85,421$ & 62.34 & 217.22 & 45.18 \\
\hline $1990-91$ & $23,27,362$ & 56.68 & 277.53 & 70.80 \\
\hline $2000-01$ & $33,73,520$ & 44.95 & 327.92 & 102.62 \\
\hline $2010-11$ & $46,76,838$ & 38.63 & 386.24 & 142.27 \\
\hline $2015-16$ & $56,03,293$ & 19.80 & 446.82 & 170.45 \\
\hline \% increase over 1950-51 & 1301.02 & \\
\hline
\end{tabular}

Note: 1)Total Geographical Area of the Country 32,87,263 sq.kms.

2)The original table used for the above table is shown in appendix-1.

\# Distributed based on the respective period of total population of the Country Census Report 1951 to 2011.

* Figures of population have been taken from Office of the Registrar General and Census Commissioner, India, Projected Total Population of India for 2015 is 1254019 thousand.

Source: Basic Road Statistics in India, 2015-16, Government of India, Ministry of Road Transport and Highways Transport Research Wing, New Delhi, www.morth.nic.in. Retrieved on 20-05-2018, 11.00 a.m.

The statistical data provided in the table 3 reveals that between the years of 1951 and 2016 growth in respect of the total road recorded was 74.45 per cent. During 1951-2016 the India's total road network about 1301.62 percentage growth and nearly 13.01 times expansion in India. It can also be observed that the highest rate is witnessed between 1960-61 to 1970-71. 
International Journal of Social Science and Economic Research

ISSN: 2455-8834

Volume:06, Issue:02 "February 2021"

Further, it is also found that during 65 years period the total road length of per lakh population and per 100 sq.km increased respectively from $110.76 \mathrm{~km}$ and $12.16 \mathrm{~km}$ in $1950-51$ to 446.82 $\mathrm{km}$ and $170.45 \mathrm{~km}$ in 2015-16.

\subsection{An Overview of Road Network in India}

Road network is vital for the sustainable and inclusive growth of the economy. Table 4 gives the information about India's Road Network in different categories as on March 2016.

Table-4

\section{Road Density in India, 2015-16 (Road Length in kms.)}

\begin{tabular}{|l|l|l|l|l|}
\hline Category & $\begin{array}{l}\text { Road Length } \\
(\mathrm{Kms})\end{array}$ & $\begin{array}{l}\text { Share of Road } \\
\text { Length }(\boldsymbol{\%})\end{array}$ & $\begin{array}{l}\text { Length of Road } \\
\text { per Lakh } \\
\text { Population* }\end{array}$ & Per 100 sq.kms. \\
\hline $\mathbf{( 0 1 )}$ & $(02)$ & $\mathbf{( 0 3 )}$ & $\mathbf{( 0 4 )}$ & $\mathbf{( 0 5 )}$ \\
\hline National Highways & $1,01,011$ & 1.80 & 8.05 & 3.07 \\
\hline State Highways & $1,76,166$ & 3.14 & 14.04 & 5.35 \\
\hline Other PWD Roads & $5,61,940$ & 10.03 & 44.81 & 17.10 \\
\hline Rural Roads & $39,35,337$ & 70.23 & $472.00^{\#}$ & 119.71 \\
\hline Urban Roads & $5,09,730$ & 9.10 & $135.16^{\#}$ & 15.50 \\
\hline Project Roads & $3,19,109$ & 5.70 & 25.44 & 9.70 \\
\hline Total & $56,03,293$ & 100.00 & 446.82 & 170.45 \\
\hline
\end{tabular}

Note: 1)Total Geographical Area of the Country 32,87,263 sq.kms.

2)The original table used for the above table is shown in appendix-1

* Figures of population have been taken from Office of the Registrar General and Census Commissioner, India, Projected Total Population of India for 2015 is 1254019 thousand.

\# According to the Census of India 2011, Rural Population was 83,37,48,852 and Urban Population was 37,71,06,125.

Source: Basic Road Statistics in India, 2015-16, Government of India, Ministry of Road Transport and Highways Transport Research Wing, New Delhi, www.morth.nic.in. (Retrieved on 20-052018, 11.00 a.m.)

The statistical information provided in the Table 4 reveals the fact that India's total road network as on March 2016 which was 56,03,293 $\mathrm{kms}$ and the total road length per lakh population was 446.82 per 100 sq.k.m. as $170.45 \mathrm{~km}$. In the total road length rural road has highest percentage with 70.23 per cent of share in total per lakh population 472 and per 100 sq.k.m. has $119.71 \mathrm{~km}$. Further, National Highway share 1.80 per cent and State Highway share has 3.14 per lakh population of $\mathrm{NH}$ and $\mathrm{SH}$ has 8.05 and 14.04 respectively and per 100 sq.k.m. has $3.07 \mathrm{~km}$ and $5.37 \mathrm{~km}$ respectively. 
International Journal of Social Science and Economic Research

ISSN: 2455-8834

Volume:06, Issue:02 "February 2021"

\subsection{International Comparison of Road Network}

Table 5 gives information on International Comparison of Road Network as on March 2016 and also shows the comparison of road density, share of paved road, total highways, motorways and National Highways.

Table-5

Major Road Indicators across Select Countries (2013-14--2015-16)

\begin{tabular}{|c|c|c|c|c|c|c|}
\hline \multirow{2}{*}{ Country } & & \multirow{2}{*}{$\begin{array}{l}\text { Road Density } \\
(\mathbf{k m} / \mathbf{s q} \cdot \mathbf{k m})\end{array}$} & \multirow{2}{*}{$\begin{array}{l}\text { Share of } \\
\text { Paved Road } \\
(\%)\end{array}$} & \multicolumn{2}{|c|}{ Road Length (kms) } & \multirow{3}{*}{ (06) } \\
\hline & & & & Motor Ways & $\begin{array}{l}\text { National } \\
\text { Highways }\end{array}$ & \\
\hline \multicolumn{2}{|l|}{$(01)$} & $(\mathbf{0 2})$ & (03) & (04) & $(\mathbf{0 5})$ & \\
\hline \multirow{2}{*}{ Brazil } & 2013-14 & 0.18 & 13.0 & $15,61,920$ & NA & $\begin{array}{l}77,981 \\
(4.99)\end{array}$ \\
\hline & $2014-15$ & 0.18 & 13.6 & $15,66,415$ & NA & $\begin{array}{l}79,378 \\
(5.08)\end{array}$ \\
\hline \multirow{2}{*}{ China } & 2013-14 & 0.46 & 67.89 & $43,56,218$ & $\begin{array}{l}1,04,438 \\
(2.40)\end{array}$ & $\begin{array}{l}74,491 \\
(1.71)\end{array}$ \\
\hline & $2014-15$ & 0.47 & NA & $44,63,913$ & $\begin{array}{l}1,11,936 \\
(2.51)\end{array}$ & $\begin{array}{l}85,362 \\
(1.91)\end{array}$ \\
\hline
\end{tabular}

\begin{tabular}{|l|l|l|l|l|l|l|}
\hline \multirow{4}{*}{ France } & $2013-14$ & 1.94 & 100.00 & $10,64,862$ & $\begin{array}{l}11,649 \\
(1.09)\end{array}$ & $\begin{array}{l}8,898 \\
(0.84)\end{array}$ \\
\cline { 2 - 7 } & $2014-15$ & 1.95 & 100.00 & $10,71,176$ & $\begin{array}{l}11,662 \\
(1.09)\end{array}$ & $\begin{array}{l}8,901 \\
(0.83)\end{array}$ \\
\hline \multirow{4}{*}{ India } & $2013-14$ & 1.64 & 59.61 & $54,02,486$ & NA & $\begin{array}{l}91,287 \\
(1.69)\end{array}$ \\
\cline { 2 - 7 } & $2014-15$ & 1.66 & 61.05 & $54,72,144$ & NA & $\begin{array}{l}97,991 \\
(1.79)\end{array}$ \\
\cline { 2 - 7 } & $2015-16$ & 1.70 & 62.50 & $56,03,293$ & NA & $\begin{array}{l}1,01,011 \\
(1.80)\end{array}$ \\
\hline \multirow{3}{*}{ Japan } & $2013-14$ & 0.91 & NA & $3,43,740$ & $\begin{array}{l}8,358 \\
(2.43)\end{array}$ & $\begin{array}{l}51,489 \\
(14.98)\end{array}$ \\
\cline { 2 - 7 } & $2014-15$ & 0.91 & NA & $3,45,828$ & $\begin{array}{l}8,428 \\
(2.44)\end{array}$ & $\begin{array}{l}51,750 \\
(14.96)\end{array}$ \\
\hline \multirow{3}{*}{$\begin{array}{l}\text { Korea } \\
\text { Republic }\end{array}$} & $2013-14$ & 1.06 & 82.51 & $1,06,414$ & $\begin{array}{l}4,112 \\
(3.86)\end{array}$ & $\begin{array}{l}13,843 \\
(13.01)\end{array}$ \\
\cline { 2 - 7 } & $2014-15$ & 1.06 & 84.90 & $1,05,673$ & $\begin{array}{l}4,139 \\
(3.92)\end{array}$ & $\begin{array}{l}13,950 \\
(13.20)\end{array}$ \\
\hline \multirow{2}{*}{$\begin{array}{l}\text { Russian } \\
\text { Federation }\end{array}$} & $2013-14$ & 0.08 & 70.54 & $13,95,603$ & $\begin{array}{l}475 \\
(0.03)\end{array}$ & $\begin{array}{l}50,388 \\
(3.60)\end{array}$ \\
\cline { 2 - 7 } & $2014-15$ & 0.08 & 70.60 & $14,50,000$ & $\begin{array}{l}4,139 \\
(3.92)\end{array}$ & $\begin{array}{l}13,950 \\
(13.20)\end{array}$ \\
\hline $\begin{array}{l}\text { The United } \\
\text { Kingdom }\end{array}$ & $2013-14$ & 1.73 & 100.00 & $4,20,949$ & $\begin{array}{l}3,756 \\
(0.89)\end{array}$ & $\begin{array}{l}49,038 \\
(11.65)\end{array}$ \\
\hline
\end{tabular}


International Journal of Social Science and Economic Research

ISSN: 2455-8834

Volume:06, Issue:02 "February 2021"

\begin{tabular}{|l|l|l|l|l|l|l|}
\hline & $2014-15$ & 1.73 & 100.00 & $4,21,127$ & $\begin{array}{l}3,760 \\
(0.59)\end{array}$ & $\begin{array}{l}49,075 \\
(11.65)\end{array}$ \\
\hline \multirow{3}{*}{ The USA } & $2013-14$ & 0.67 & 65.78 & $65,50,896$ & $\begin{array}{l}73,366 \\
(1.11)\end{array}$ & $\begin{array}{l}76,335 \\
(1.13)\end{array}$ \\
\cline { 2 - 7 } & $2014-15$ & 0.68 & 65.90 & $67,02,178$ & $\begin{array}{l}24,297 \\
(0.37)\end{array}$ & $\begin{array}{l}27,066 \\
(0.40)\end{array}$ \\
\hline
\end{tabular}

Note :1) NA - Information Not Available

2) Columns $5 \& 6$, Figures in Parenthesis indicate the percentage share of the category in Total Road Length.

Source :1) For - India - Transport Research Wing, Ministry of Road Transport and Highways.

2) For all other countries, 'World Road Statistics 2015 and 16' Published by International Road Federation, Geneva.

3) Basic Road Statistics in India, 2013-14, 2014-15 and 2015-16, Government of India, Ministry of Road Transport and Highways Transport Research Wing, New Delhi, September 2017 (www.morth.nic.in.)

As on 31st March 2016, India's road density is at $1.70 \mathrm{~km} / \mathrm{sq} . \mathrm{km}$ of area which was higher than other that of Japan $(0.91 \mathrm{~km} / \mathrm{sq} . \mathrm{km})$, USA $(0.68 \mathrm{~km} / \mathrm{sq} . \mathrm{km})$, China $(0.47 \mathrm{~km} / \mathrm{sq} . \mathrm{km})$, Brazil $(0.18$ $\mathrm{km} / \mathrm{sq} . \mathrm{km})$ and Russian Federation $(0.08 \mathrm{~km} / \mathrm{sq} . \mathrm{km})$. The surfaced road length in India was 61.03 per cent of the total road length which was lower as compared to the United Kingdom, Korea and Russian Federation. National Highways (NHs) in India accounted for 1.76 per cent of the total road length as on 31st March 2016. Details are present in Table 5.

\subsection{Growth of Road Transport in India (1951 to 2016)}

Table 6. gives the information about comparison of the growth of Road into pre-liberalization and post-liberalization and also gives percentage increase of road category during the period between 1950-51 and 2015-16.

\section{Table-6}

\section{Growth of Road Transport in India from 1950-51 to 2015-16}

\begin{tabular}{|l|l|l|l|}
\hline Category of Roads & $\begin{array}{l}\text { Pre-liberalization (1950- } \\
\mathbf{5 1} \text { to } \mathbf{1 9 9 0 - 9 1 )}\end{array}$ & $\begin{array}{l}\text { Post-liberalization } \\
(\mathbf{1 9 9 1} \text { to 2015-16) }\end{array}$ & $\begin{array}{l}\text { \% increase over } \\
\mathbf{1 9 5 0 - 5 1} \text { to 2015-16 }\end{array}$ \\
\hline $\mathbf{( 0 1 )}$ & $\mathbf{( 0 2 )}$ & $\mathbf{( 0 3 )}$ & $\mathbf{( 0 4 )}$ \\
\hline National Highways & 69.85 & 200.18 & 409.87 \\
\hline State Highways & 124.28 & 38.37 & $210.35^{*}$ \\
\hline Other PWD Roads & 193.24 & 10.30 & 223.46 \\
\hline Rural Roads & 510.64 & 212.22 & 1806.58 \\
\hline Urban Roads & 303.18 & 172.87 & $999.48^{\#}$ \\
\hline Project Roads & 60.23 & 52.14 & $143.79^{*}$ \\
\hline Total & 481.92 & 140.75 & 1301.02 \\
\hline
\end{tabular}

Note: 1) * Over the period 1970-71 and 2) ${ }^{\#}$ Over the period 1960-61.

3)The original table used for the above table is shown in appendix-1. 
International Journal of Social Science and Economic Research

ISSN: 2455-8834

Volume:06, Issue:02 "February 2021"

Source: Basic Road Statistics in India, 2015-16, Government of India, Ministry of Road Transport and Highways Transport Research Wing, New Delhi, www.morth.nic.in. Retrieved on 20-05-2018, 11.00 a.m.

Statistical information about growth of Road Transport in India from 1950-51 to 2015-16 is given in Table 6. Total road length increased by 1301.02 percentage points. In the total road length rural road length has been the highest percentage of 1806.58 percentage points. In a oreliberalization period rural road length is highest which has been 510.64 percentage points followed by Urban Roads (303.18 percentage points), Other PWD Roads (193.24 percentage points), State Highways (124.28 percentage points) and National Highways (69.85 percentage points) and Project Roads (60.23 percentage points).

In a post-liberalization period National Highways growth was the highest with 200.18 percentage points. The proactive policy steps such as leveraging of private and public investment, innovative financing models have resulted in an increase in the pace of National Highway Development during post-liberalization period.

\subsection{Compound Annual Growth Rate of India's Road Network}

The information about CAGR of road network in India 1951 to 2016, in the given table 7.

Table-7

CAGR (\%) of Road Connectivity in India, 1950 to 2016

\begin{tabular}{|c|c|c|c|c|c|c|c|}
\hline \multirow[b]{2}{*}{ Period } & \multicolumn{6}{|c|}{ Roads } & \multirow[b]{2}{*}{$\begin{array}{l}\text { Total \% } \\
\text { crease over } \\
\text { periods }\end{array}$} \\
\hline & NHs & $\begin{array}{c}\text { SHs and } \\
\text { District } \\
\text { Roads }\end{array}$ & Rural & Urban & Project & Total & \\
\hline $2016 / 1951$ & 2.5 & 3.2 & 4.4 & - & - & 4.1 & 1301.02 \\
\hline $1961 / 1951$ & 1.9 & 4 & -0.5 & - & - & 2.7 & 31.13 \\
\hline $1971 / 1961$ & 0 & 2.6 & 6 & 4.5 & - & 5.7 & 74.45 \\
\hline 1981/1971 & 2.9 & 4.5 & 5.9 & 5.5 & 2.1 & 5 & 62.34 \\
\hline 1991/1981 & 0.6 & 2.1 & 7.2 & 4.3 & 1.2 & 4.6 & 56.68 \\
\hline $2001 / 1991$ & 5.5 & 3.1 & 4.6 & 3 & 0.6 & 3.8 & 44.95 \\
\hline $2014 / 2004$ & 3.4 & 3.9 & 4.4 & 4.3 & 1.3 & 4.1 & - \\
\hline $2015 / 2005$ & 4.1 & 3.1 & 3.9 & 5 & 1.5 & 3.7 & - \\
\hline $2016 / 2006$ & 4.3 & $*$ & 5.5 & 5.7 & 2.0 & 3.7 & - \\
\hline
\end{tabular}

Note: 1) CAGR - Compound Annual Growth Rate

2) During the year 2015-16 Other PWD Road (OPWD) category has been discontinued and PWD road other than SHs, are categorized under District Roads and Rural Roads under PWD. Because of this change the figures in respect of OPWD, District Road and Rural Roads are not comparable with figures and previous years. 
International Journal of Social Science and Economic Research

ISSN: 2455-8834

Volume:06, Issue:02 "February 2021"

3)The original table used for the above table is shown in appendix-1.

Source: Basic Road Statistics in India, 2015-16, Government of India, Ministry of Road Transport and Highways Transport Research Wing, New Delhi, www.morth.nic.in.

The total length of the country increased significantly from 3.99 lakh kms in 1951 to 56.03 lakh in 2016 with growing a Compound Annual Growth Rate (CAGR) of 4.1 per cent during the year 1951 to 2016. The long run growth in road CAGR for 1951-2016 along with decadal CAGRs are given in Table 7.

During the decade, 2005-06 to 2015-16 the highest CAGR was that of urban roads (5.7 per cent) followed by rural roads ( 5.5 per cent), $\mathrm{NH}$ (4.3 per cent) and project roads ( 2.0 per cent). The length of National Highway was $70,934 \mathrm{kms}$ in $2010-11$ and it increased rapidly to $1,01,011 \mathrm{kms}$ in 2015-16.

\subsection{Findings of the study}

1. The total road length of the country increased significantly from 3.99 lakh $\mathrm{kms}$ in 1951 to 56.03 lakh kms in 2016 with a growing a CAGR 84.1 per cent during the year 1951 to 2016 and also surfaced road formed. 39.26 per cent which increased to 62.5 per cent during the period between 1951 and 2016. India's road density at $170 \mathrm{~km}$ was higher than that of Japan $(0.91 \mathrm{~km})$, the USA $(0.68 \mathrm{~km})$, China $(0.47 \mathrm{~km})$ and Brazil $(0.18 \mathrm{~km})$.

2. The state-wise growth shows that the Maharashtra $(613418 \mathrm{kms})$ accounted for the largest share of 13.04 per cent in total network of roads for the year up to the period March 2016 followed by Uttar Pradesh share of 8.98 per cent, Karnataka share of 7.35 per cent, Assam share of 7.01 per cent and West Bengal share of 6.73 per cent and combined these states.

3. Between the years of growth in respect of the total road recorded was 74.45 per cent in the decade 1951-2016 the India's total road network about 1301.62 percentage growths and nearly 13.01 times expansion in India. It can also be observed that the highest rate 1960-61 to 1970-71.

4. During 65 years period the total road length of per lakh population and per 100 sq.km, increased respectively from $110.76 \mathrm{~km}$ and $12.16 \mathrm{~km}$ in $1950-51$ to $446.82 \mathrm{~km}$ and 170.45 $\mathrm{km}$ in 2015-16.

5. India's total road network as on March 2016 was 56,03,293 kms the total road length of per lakh population 446.82 and per 100 sq. km. has $170.45 \mathrm{~km}$. In the total road length rural road has the highest amounted of 70.23 per cent of share in total per lakh population 472 and per 
International Journal of Social Science and Economic Research

ISSN: 2455-8834

Volume:06, Issue:02 "February 2021"

100 sq.km. has $119.71 \mathrm{~km}$. National Highway share was 1.80 per cent and State Highway share has 3.14 per lakh population of $\mathrm{NH}$ and $\mathrm{SH}$ has 8.05 and 14.04 respectively and per $100 \mathrm{sq} . \mathrm{km}$. has $3.07 \mathrm{~km}$ and $5.37 \mathrm{~km}$ respectively.

6. India's road density at $1.70 \mathrm{~km} / \mathrm{sq} . \mathrm{km}$ of area was higher than other that of Japan $(0.91$ $\mathrm{km} / \mathrm{sq} . \mathrm{km})$, USA $(0.68 \mathrm{~km} / \mathrm{sq} . \mathrm{km})$, China $(0.47 \mathrm{~km} / \mathrm{sq} . \mathrm{km})$, Brazil $(0.18 \mathrm{~km} / \mathrm{sq} . \mathrm{km})$ and Russian Federation $(0.08 \mathrm{~km} / \mathrm{sq} . \mathrm{km})$. The surfaced road length in India was 61.03 per cent of the total road length which was lower as compared to the United Kingdom, Korea and Russian Federation, National Highways (NHs) in India, accounted for 1.76 per cent of the total road length as on 31st March 2016.

7. Growth of Road Transport in India, 1950-51 to 2015-16 total road length was increased 1301.02 percentage points. In the total road length rural road length has been highest amounting to 1806.58 percentage points. In a pee-liberalization period rural roads length highest has been 510.64 percentage points followed by Urban roads (303.18 percentage points), Other PWD Roads (193.24 percentage points), State Highways (124.28 percentage points) and National Highways (69.85 percentage points) and Project Roads (60.23 percentage points).

8. In a post-liberalization National Highways growth was the highest with 200.18 percentage points. The proactive steps, leveraging of private and public investment, innovative financing models have resulted in increased in pace of National Highway development in postliberalization.

9. The total length of the country increased significantly from 3.99 lakh kms in 1951 to 56.03 lakh in 2016 with growing a Compound Annual Growth Rate (CAGR) of 4.1 per cent during the year 1951 to 2016 .

10. During the decade, 2005-06 to 2015-16, the highest CAGR was that of urban roads (5.7 per cent) followed by rural roads (5.5 per cent), NH (4.3 per cent) and project roads (2.0 per cent). The length of National Highway was $70,934 \mathrm{kms}$ in 2010-11 it increased rapidly to $1,01,011 \mathrm{kms}$ in 2015-16.

\subsection{Conclusion}

A good road network is a critical infrastructure requirement for rapid growth of the economy. Roads should not be looked at in isolation but as a part of an integrated multi-model system of transport various construction programmes for different classes of roads over the past two and a half decades have yielded a significant expansion in network size in India. Efforts are being 
International Journal of Social Science and Economic Research

ISSN: 2455-8834

Volume:06, Issue:02 "February 2021"

made for a balanced development of road network (primary, secondary and tertiary system). In comparison to other modes of transport, the movement of passenger and freight in India over the years has increasingly shifted towards road transport sector. Thus, Road transport is vital to the economic development and social integration of the country. Road transport fulfills a major role in the Indian economy involving a wide range of industries and services from vehicle manufacturers and suppliers to infrastructure builders, services, energy providers, public authorities, insurance and many others. Road transport, together with the other modes of transport, provides indispensable mobility for all citizens and goods and contributes to the economic prosperity of a nation. It is a key factor to social, regional and economic cohesion including the development of rural areas. However, the impact of road transport on the environment and health remains a major challenge in many aspects. Easy accessibility, flexibility of operations, door-to door service and reliability have earned road transport an increasingly higher share of both passenger and freight traffic vis-à-vis other transport modes. The alternative modes of transport viz. roadways, railways, waterways, airways, etc., each contribute to the transportation requirements of the economy.

\section{References}

1. India 2018, A Reference Annual New Media wing, Publication division, Ministry of information \& Broadcasting, Government of India, New Delhi March 2018 P.726

2. Basic Road Statistics in India, 2015-16, Government of India, Ministry of Road Transport and Highways Transport Research Wing, New Delhi, www.morth.nic.in. Retrieved on 2005-2018, 11.00 a.m. p.04.

3. Ibid. p.07.

4. William L. Garison (1960), in a study entitled Connectivity of the Interstate Highway System, Regional Science (RSAI), January 1960, Vol. 6, Issue 1, pp. 7-214.

5. Vijayaraghavan (1995), Strategic Options for State Road Transport Undertakings in India,.International Journal of Public Sector Management, 1995, Vol. 8, Issue 1, pp. 48-67.

6. Food and Agriculture Organization (1996) (FOA) Report, United Nations, Chapter 10, p.15.

7. Mazharul (1998), The Accident Problem on Rural Highways, Journal of Civil Engineering, The Institution of Engineers, Bangladesh, Vol. CE26, No. 1, pp. 51-59. 
International Journal of Social Science and Economic Research

ISSN: 2455-8834

Volume:06, Issue:02 "February 2021"

8. Talvitie (2000), Evaluation of Road Projects and Programmes in Developing Countries, Journal of Transport Policy, Vol. 7, Elsevier Scientific Ltd., pp. 61-72 (www.elsevier.com)

9. B.C. Vaidya (2003), in his book entitled Geography of Transport Development in India, Publishing Company, New Delhi, 2003, ISBN 81-7022-957-X.

10. Sing A.P. et al. (2009), Road Safety Improvement: A Challenging Issue on Indian Roads, University of Michigan Transportation Research Institute, USA, Jan. 2009, pp. 1-69.

11. Tarique (2009)., Rural Infrastructure and Economic Development, , Kurukshetra- A Journal of Rural Development, Ministry of I and B, Government of India, Vol. 57, No. 12, October 2009, pp.12-13.

12. Pravakon Sahoo (2011, Transport Infrastructure in India: Developments, Challenges and Lessons from Japan, V.R.F. Series, Institute of Development Economics, March 2011, No. 465, Japan External Trade Organization, pp. 1-72.

13. Krishna Dev (2017), Union Budget 2017-18: A Take-off for Infrastructure Sector, Yojana A Development Monthly, Vol. 61, March 2017 (Special Issue), Published by Ministry of I\&B, GoI, New Delhi.pp.13-14.

14. Nagpur plan has classified Indian roads into five groups. They are, National Highways (NHs), State Highways (SHs), Major District Roads (MDRs), Other District Roads (ODRs) and Village Roads (VRs),

15. B. Jayarama Bhat (2018). "Road Transport in India”, Shreyas Publication, Shivamogga, Karnataka, p.70.

16. Basic Road Statistics in India, 2015-16, Government of India, Ministry of Road Transport and Highways Transport Research Wing, New Delhi, www.morth.nic.in. Retrieved on 2005-2018, 11.00 a.m. p.25.

17. Annual Plan Report, 2006-07 to 2015-16, Government of India.

18. Atanu Sengupta and Ashish Kumar Pal (2015-16). "Urban Sustainable Transportation Development: A Case of West Bengal", The Indian Journal of Economics, Vol. XCVI, No. 381, Part II, pp. 238-251.

19. Basic Road Statistics in India, 2015-15, Government of India, Ministry of Transport and Highways, IPA Building, Jammanagar House, Shahijahan Road, New Delhi, pp. 1-90. 
International Journal of Social Science and Economic Research

ISSN: 2455-8834

Volume:06, Issue:02 "February 2021"

20. Hemachandra P.N. (2016). "Structural Changes in The Rural Economy of Hassan District A Geographical Analysis", Journal of Development and Social Change, Vol. XII, No. 3\&4, pp. 4-13, ISSN: 2231-0991.

21. India - 2018, A Reference Annual, 2018, 62nd Edition, New Media Wing, Ministry of Information and Broadcasting, Government of India, pp. 725-734.

22. J.K. Chopra (2016). "Economics, A Complete Resource Manual”, Unique Publishers Pvt. Ltd., New Delhi - 110024, pp. 107-122, ISBN: 978-93-5187-427-0.

23. Padmanabha (1981). "Salient Features", Census of India, India International Centre Quarterly Journal, Vol. 8, No. 3-4, India’s Population: Problems and Perspectives (1981), pp. 207-218, www.jstor.org.

24. Rural Infrastructure, India Infrastructural Report 2007, Oxford University press, New Delhi, pp.109-13.

25. Yuvaraj U. and B. Jayarama Bhat (2016). "Regional Disparities of Rural Road Connectivity in Karnataka: An Analysis", Global Journal for Research Analysis, Vol. 5, Issue 12, pp.215-219. 


\section{International Journal of Social Science and Economic Research}

ISSN: 2455-8834

Volume:06, Issue:02 "February 2021"

\section{Appendix-01}

\section{Road Network in India(Length in kms)}

\begin{tabular}{|c|c|c|c|c|c|c|c|c|c|c|c|}
\hline $\begin{array}{c}\text { Years } \rightarrow \\
\text { Category of Roads } \downarrow\end{array}$ & $1950-51$ & 1960-61 & 1970-71 & $1980-81$ & 1990-91 & 2000-01 & 2010-11 & 2012-13 & 2014-15 & 2015-16 & $\begin{array}{c}\text { Percentage } \\
\text { increase over 1950- } \\
51 \text { to } 2015-16\end{array}$ \\
\hline$(01)$ & $(\mathbf{0 2})$ & $(\mathbf{0 3})$ & $(04)$ & $(05)$ & (06) & $(07)$ & $(08)$ & $(09)$ & (10) & (11) & $(12)$ \\
\hline National Highways & $\begin{array}{c}19,811 \\
(-)\end{array}$ & $\begin{array}{l}23,798 \\
(20.12)\end{array}$ & $\begin{array}{c}23,838 \\
(0.16)\end{array}$ & $\begin{array}{l}31,371 \\
(32.85)\end{array}$ & $\begin{array}{l}33,650 \\
(06.24)\end{array}$ & $\begin{array}{l}57,737 \\
(71.58)\end{array}$ & $70,934(22.85)$ & $\begin{array}{l}79,116 \\
(11.53)\end{array}$ & $\begin{array}{l}97,991 \\
(23.85)\end{array}$ & $\begin{array}{c}1,01,011 \\
(3.08)\end{array}$ & 409.87 \\
\hline Percentage to total & 04.95 & 4.53 & 2.60 & 2.13 & 1.14 & 1.71 & 1.51 & 1.51 & 1.79 & 1.80 & \\
\hline State Highways & - & - & $\begin{array}{c}56,763 \\
(-)\end{array}$ & $\begin{array}{l}94,359 \\
(66.22)\end{array}$ & $\begin{array}{c}1,27,311 \\
(34.92)\end{array}$ & $\begin{array}{c}1,32,100 \\
(3.76)\end{array}$ & $\begin{array}{c}1,63,898 \\
(24.07)\end{array}$ & $\begin{array}{c}1,69,227 \\
(3.25)\end{array}$ & $\begin{array}{c}1,67,109(- \\
1.25)\end{array}$ & $\begin{array}{c}1,76,166 \\
(5.41)\end{array}$ & $210.35^{*}$ \\
\hline Percentage to total & - & - & 6.20 & 6.35 & 5.47 & 3.91 & 3.50 & 3.23 & 3.05 & 3.14 & \\
\hline Other PWD Roads & $1,73,723(-)$ & $\begin{array}{c}2,57,125 \\
(48.00)\end{array}$ & $\begin{array}{c}2,76,833 \\
(7.66)\end{array}$ & $\begin{array}{c}4,21,895 \\
(52.40)\end{array}$ & $\begin{array}{c}5,09,435 \\
(20.74)\end{array}$ & $\begin{array}{c}7,36,001 \\
(44.47)\end{array}$ & $\begin{array}{c}9,98,895 \\
(35.71)\end{array}$ & $\begin{array}{c}10,66,747 \\
(6.79)\end{array}$ & $\begin{array}{c}11,01,178 \\
(3.22)\end{array}$ & $\begin{array}{c}5,61,940 \\
(-48.96)\end{array}$ & 223.46 \\
\hline Percentage to total & 43.43 & 49.05 & 30.25 & 28.40 & 21.88 & 21.81 & 21.35 & 20.8 & 20.12 & 10.03 & \\
\hline Rural Roads & $2,06,408(-)$ & $\begin{array}{c}1,97,194(- \\
4.46)\end{array}$ & $\begin{array}{c}3,54,530 \\
(79.79)\end{array}$ & $\begin{array}{c}6,28,865 \\
(77.38)\end{array}$ & $\begin{array}{c}12,60,430 \\
(100.43)\end{array}$ & $\begin{array}{c}19,72,016 \\
(56.46)\end{array}$ & $\begin{array}{c}27,49,804 \\
(39.44)\end{array}$ & $\begin{array}{c}31,59,639 \\
(14.90)\end{array}$ & $\begin{array}{c}33,37,255 \\
(5.62)\end{array}$ & $\begin{array}{c}39,35,337 \\
(17.92)\end{array}$ & 1806.58 \\
\hline Percentage to total & 51.62 & 37.59 & 38.77 & 42.36 & 54.18 & 58.45 & 58.82 & 60.42 & 61.00 & 70.23 & \\
\hline Urban Roads & - & $46,361 \quad(-)$ & $\begin{array}{l}72,120 \\
(55.69)\end{array}$ & $\begin{array}{c}1,23,120 \\
(70.71)\end{array}$ & $\begin{array}{c}1,86,799 \\
(51.72)\end{array}$ & $\begin{array}{c}2,52,001 \\
(34.90)\end{array}$ & $\begin{array}{c}4,11,679 \\
(63.36)\end{array}$ & $\begin{array}{c}4,46,238 \\
(8.39)\end{array}$ & $\begin{array}{c}4,67,106 \\
(04.67)\end{array}$ & $\begin{array}{c}5,09,730 \\
(9.55)\end{array}$ & $999.48 \oplus$ \\
\hline Percentage to total & - & 8.83 & 7.88 & 8.28 & 8.02 & 7.46 & 8.80 & 8.52 & 8.54 & 9.10 & \\
\hline Project Roads & - & - & $1,30,893(-)$ & $\begin{array}{c}1,85,511 \\
(41.72)\end{array}$ & $\begin{array}{c}2,09,737 \\
(13.05)\end{array}$ & $\begin{array}{c}2,23,665 \\
(6.64)\end{array}$ & $\begin{array}{c}2,81,628 \\
(25.91)\end{array}$ & $\begin{array}{c}3,10,955 \\
(10.41)\end{array}$ & $\begin{array}{c}3,01,505(- \\
30.39)\end{array}$ & $\begin{array}{c}3,19,109 \\
(5.83)\end{array}$ & $143.79^{*}$ \\
\hline Percentage to total & - & - & 14.30 & 12.48 & 9.01 & 6.63 & 6.02 & 5.94 & 5.50 & 5.70 & \\
\hline Total & $3,99,942(-)$ & $\begin{array}{c}5,24,478 \\
(31.13)\end{array}$ & $\begin{array}{c}9,14,979 \\
(74.45)\end{array}$ & $\begin{array}{c}14,85,421 \\
(62.34)\end{array}$ & $23,27,362(56.68)$ & $\begin{array}{c}33,73,520 \\
(44.95)\end{array}$ & $\begin{array}{c}46,76,838 \\
(38.63)\end{array}$ & $\begin{array}{c}52,31,922 \\
(11.86)\end{array}$ & $\begin{array}{c}54,72,144 \\
(4.59)\end{array}$ & $\begin{array}{c}56,03,293 \\
(2.39)\end{array}$ & 1301.02 \\
\hline & 100.00 & 100.00 & 100.00 & 100.00 & 100.00 & 100.00 & 100.00 & 100.00 & 100.00 & 100.00 & \\
\hline
\end{tabular}

Note: 1) Figures in brackets show percentage change over the previous period, 2) * over the period 1970-71 and 3) $\oplus$ over the period 1960-61

Source: Basic Road Statistics of India, 2015-16 Government of India, Ministry of Road Transport and Highways, Transport Research Wing, New Delhi, pp.2-7

http://www.basicroadstatisticsofindia.com Retrieved on 20-02-2018, 11.00 Am. 